\title{
A háziorvos feladatai a diabetes mellitus kórismézésében, a cukorbetegek antihyperglykaemiás kezelésében és gondozásában felnőttkorban
}

\author{
Magyar Diabetes Társaság (MDT) Háziorvosi Munkacsoportja
}

\begin{abstract}
A kéziratot összeállította: Dr. Oláh Ilona, véleményezte: Dr. Szabó János, Dr. Rosta László, Dr. Preiszinger Andrea, Dr. Kajetán Miklós, Dr. Torzsa Péter, Dr. Kalabay László
\end{abstract}

\begin{abstract}
Ósszefoglalás
A nagyszámú hazai cukorbeteg ellátása az alapellátás számára komoly feladat, a háziorvosi munka jelentós része. Az alapellátás számára elsösorban a 2-es típusú cukorbetegek ellátása területén mutatkozik számos teendő. A közlemény csatlakozva „A diabetes mellitus kórismézéséröl, a cukorbetegek antihyperglykaemiás kezeléséröl és gondozásáról felnöttkorban" cimü szakmai irányelvhez - a háziorvosi feladatokat összegzi.

- Kulcsszavak: cukorbeteg-gondozás, 2-es típusú diabetes, prediabetes, diabetes-szürés, kardiovaszkuláris kockázat, háziorvosi ellátás

The task of GP-s in the diagnosis of diabetes mellitus, in the antihyperglycaemic treatment and care of the adult patients with diabetes

Summary: The health service of the numerous patients with diabetes mellitus represents a serious challenge and encompasses a significant part of the general practitioner's work. It is mainly the management of patients with type 2 diabetes that represents numerous tasks in primary care setting. In accordance with the guideline "On the diagnosis and antihyperglycemic treatment and management of adults with diabetes mellitus" this paper summarises the tasks of the general practitioner.

- Key words: diabetes care, type 2 diabetes, prediabetes, screening for diabetes, cardiovascular risk, primary care
\end{abstract}

Rövidítések

BMI: testtömeg-index (body mass index); DPP-4: dipeptidilpeptidáz-4; eGFR: becsült (estimated) glomeruláris filtrációs ráta; GDM: gesztációs diabetes mellitus; GLP-1: glukagonszerü peptid-1; $\mathbf{H b A}_{1 \mathbf{1 c}}$ : hemoglobin $\mathrm{A}_{1 c}$; $\mathbf{H D L}$ : nagy denzitású lipoprotein (high density lipoprotein); IFG: emelkedett éhomi vércukor (impaired fasting glycaemia); IGT: csökkent glukóztolerancia (impaired glucose tolerance); LADA: lassú kialakulású autoimmun diabetes a felnőttkorban (latent autoimmune diabetes in adults); LDL: alacsony denzitású lipoprotein (low density lipoprotein); OAD: orális antidiabetikum; OGTT: orális glukóztolerancia-teszt; SGLT: nátrium-glukóz kotranszporter (sodium-glucose cotransporter)

\footnotetext{
A közleményben hivatkozott ábrák és táblázatok azonosak „A diabetes mellitus kórismézéséről, a cukorbetegek antihyperglykaemiás kezeléséről és gondozásáról felnőttkorban" címủ szakmai irányelvben szereplö ábrákkal és táblázatokkal, az eredeti számozást követve.
} 
$\mathrm{E}$ pidemiológiai adatok alapján hazánkban a cukorbetegek száma meghaladja a 700 ezer főt. A cukorbetegség nagyszámú előfordulása és súlyos szövődményei révén komoly népegészségügyi jelentőséggel bír, gondozása a háziorvosi munka jelentős része. A megelőzés területén a 2-es típusú cukorbetegség tekintetében adódik lehetőség. A háziorvos feladata a prediabetesszel (IFG, IGT) rendelkező páciensek kezelése, gondozása. Önálló háziorvosi feladat továbbá azon 2-es típusú cukorbetegek kezelése, gondozása, akiknél az anyagcsere-állapot vagy a szükséges kezelési mód nem igényli a szakellátás szoros gondozási tevékenységét. Az 1-es típusú cukorbetegség, a terhességi diabetes, az egyéb speciális diabetesformák kezelése, továbbá a 2-es típusú cukorbetegek azon eseteiben, ahol az anyagcsere-állapot, a szükséges kezelési mód vagy a szövődmények szakellátási tevékenységet igényelnek, a háziorvos a betegellátást a szakellátás útmutatásának figyelembevételével végzi.

A cukorbetegségségben szenvedők több mint 90\%-át kitevő 2-es típusú cukorbetegek primer, szekunder és tercier prevenciójában a háziorvosi team holisztikus szemléletủ gondozásának alapvető szerepe van.

\section{A cukorbetegség szürése, diagnózisa}

A háziorvos feladata a betegség időben történő felismerése, ezen túl a betegség kockázati tényezőinek feltárása és törekvés azok megszüntetésére. A kockázati tényezők, ezek alapján az időben végzett szűrővizsgálat, a megfelelő prevenció meghatározza a beteg további sorsát.

Vércukor-meghatározás indokolt diabetesre utaló tünetek (polyuria, polydipsia, más okkal nem megmagyarázható fogyás, pruritus vulvae, balanitis) fennállása, illetve súlyos tudatzavar vagy coma esetén. Ezen esetekben egyetlen vércukor-meghatározás eredménye diagnosztikus lehet, ugyanis ilyenkor a vércukor magas, s a vizeletben is cukor mutatható ki. A fentieken kívül a beteg panaszkodhat fáradtságra, az étvágytalanság mellett hányingerre, hányásra; ez utóbbiak már a ketosis tünetei lehetnek. Időnként homályos látás lép fel. Visszatérő, nehezen gyógyuló infekciók is felhívhatják a figyelmet a cukorbajra. Olykor láb- ikragörcs vagy a kézujjakon zsibbadás jelentkezik. Súlyos esetben a kialakuló hyperglykaemiás ketoacidosis vagy a nem-ketotikus hyperosmolaris állapot tudatzavarhoz, eszméletvesztéshez vezethet, és kezelés nélkül halált okozhat. Elsősorban a 2-es típusú diabetes azonban gyakran lehet tünetszegény, ilyenkor a diagnózis egy már elszenvedett szövődmény - myocardialis infarctus, stroke kapcsán derülhet ki.

Vércukor-meghatározás szűrővizsgálati jelleggel indokolt a veszélyeztetett egyének (45 éves életkor felettiek, pozitív családi anamnézissel rendelkezők, testsúlyfelesleggel [BMI $>25 \mathrm{~kg} / \mathrm{m}^{2}$ ] rendelkezők, hyperlipidaemiások, hypertoniások, nagy újszülöttet szülő nők, anamnézisben gesztációs diabetes, kórelőzményben kardiovaszkuláris megbetegedés) körében. Tünetmentes egyének esetén a diabetes kórisméjét sohasem szabad egyetlen kóros vércukorérték alapján kimondani. Követelmény, hogy ilyen esetben legalább egy további, más alkalommal történő vizsgálat eredménye is kóros legyen.

A háziorvos először éhomi vércukorvizsgálatot végez. Amennyiben az nem utal cukorbetegségre, elvégzi az OGTT vizsgálatot. Az OGTT helyes kivitelezésének kritériumait az 1. táblázat tartalmazza. Hasonló módon jár el a populációs szintű szürővizsgálatok végzésére hivatott kockázatalapú szűrőteszt, a FINDRISC kérdőív (www.diabet.hu) megfelelő pozitivitása esetén. Az éhomi vércukorszint, illetve a 120 perces OGTT eredményei alapján - az ismert diagnosztikus kritériumok szerint - történik a diagnózis felállítása (2. táblázat). Amennyiben a FINDRISC kérdőív alapján még diagnosztikus vizsgálat nem indokolt (pontszám <12), de befolyásolható kockázati tényezők jelenlétét észleli a háziorvos, megfelelő megelőzést kezdeményez, többek között segíti a beteget az ideális testsúly elérésében, a halmozott rizikóval rendelkező családokat a helyes életmód kialakításában.

Ha diabetes vagy prediabetes megállapítható, a beteg kezelését azonnal el kell kezdeni, egyben a további klasszikus kardiológiai rizikófaktorok (vérnyomás, lipidértékek) meghatározását is kezdeményezni kell. Ha a szűrővizsgálat eredménye negatív, ismételt szűrés a mindenkori jogszabályoknak megfelelően történik (51/1997. [XII. 18.] NM rendelet a kötelező egészségbiztosítás keretében igénybe vehető betegségek megelőzését és ko- 
rai felismerését szolgáló egészségügyi szolgáltatásokról és a szűrővizsgálatok igazolásáról).

\section{Teendők a diabetes mellitus felismerésekor}

A szénhidrátanyagcsere-zavar észlelésekor első teendő a klasszifikáció (4. táblázat). Az 1-es típusú cukorbetegség a felismeréskor kórházi ellátást igényel, az egyéb diabetesfajták és a GDM ellátása szakellátási feladat. A 2-es típusú diabetes felismerése általában nem okoz gondot, diagnosztikai bizonytalanság (LADA [lassan kialakuló autoimmun diabetes], pancreatogen diabetes, különleges diabetesformák gyanúja), fiatal, gyermekvállalást tervező diabetika, a diabetes mellitus felismerésekor már szövődmények, súlyos társbetegségek jelenléte esetén vagy anyagcsere-kisiklással járó esetekben (5. táblázat) mielőbbi szakorvosi vizsgálat/kórházi elhelyezés, szükség esetén diabetológiai gondozásba vétel javasolt. Amennyiben a házorvos számára bizonyos a 2-es típusú cukorbetegség diagnózisa és a fenti kritériumok nem állnak fenn, önállóan elkezdheti a beteg gondozását. El kell végezni a szükséges diagnosztikus és fizikális vizsgálatokat, valamint meg kell tennie az első edukációs és terápiás lépéseket. A diabetes felismerésekor, illetve a beteg első megjelenésekor tisztázandó körülmények, illetve elvégzendő feladatok:

- anamnézis (családi is, nőknél szülészeti események), táplálkozási és életmódi szokások, foglalkozás, fizikai aktivitás, iskolai végzettség, korábbi gyógyszeres kezelés tisztázása;

- teljes körű fizikális vizsgálat: testsúly, testmagasság, haskörfogat, vérnyomás mérése, a láb vizsgálata (talp, deformitások, gombásodás, perifériás artériák tapintása, neuropathia ellenőrzése hangvillával), EKG készítése, BMI meghatározása;

- szemfenék szemész szakorvos általi vizsgálata, tágított pupillák mellett;

- laboratóriumi vizsgálatok: $\mathrm{HbA}_{1 c}$; vércukor éhomra és postprandialisan, szérum össz-koleszterin, HDL-koleszterin, LDL-koleszterin (mérve vagy becsülve), triglicerid, kreatinin, eGFR, vizeletcukor és -aceton, üledék, szükség esetén vizelettenyésztés, kvantitatív albuminürítés (microalbuminuria).
- a betegoktatás megkezdése;

- dietetikai tanácsadás;

- az orális antidiabetikumok alkalmazásának elmagyarázása (ha aktuális);

- az inzulinterápia beállítása (ha szükséges), az ehhez szükséges injekciózási technika megtanítása (ezt a feladatot a diabetológiai szakellátó helyeken az edukátorok elvégzik, a háziorvosi team tagjainak feladata a beteg segítése, amennyiben a kezelés során probléma merül föl és a beteg nem tudja a szakellátó helyet felkeresni);

- a vércukor-önellenőrzés jelentőségének elmagyarázása (ha aktuális: megtanítása);

- dohányzással kapcsolatos tanácsadás;

- a rendszeres fogorvosi ellenőrzés fontosságának hangsúlyozása.

Meg kell adnunk a céltartományon (6,0-8,0\%) belül az adott beteg számára elérendő $\mathrm{HbA}_{1 c}$-célértéket, melyet mindig egyénileg határozunk meg. Fiatal, szövődménymentes beteg esetében szigorúbbak vagyunk, 6,0-6,5\% közötti értéket tűzünk ki, míg idősebb, multimorbid, nagy hypoglykaemia-kockázatú beteg esetén megelégszünk a 8,0\% körüli értékkel. Határozzuk meg az ideális testsúly mértékét, amit a BMI alapján tudunk kalkulálni (cél: BMI $<27 \mathrm{~kg} / \mathrm{m}^{2}$ ).

Az aktuális Kardiovaszkuláris Konszenzus Konferencia kritériumainak megfelelően meg kell határozni betegünk kardiovaszkuláris rizikóstátuszát (nagy vagy igen nagy kardiovaszkuláris rizikóval rendelkező személy), ennek függvényében a vérzsír- és vérnyomás-célértékeket, döntenünk kell az esetleges thrombocytaaggregáció-gátlás kérdéséről.

A betegedukációban sokat segíthet, ha a beteggel közösen határozzuk meg a rizikóstátuszt és az elérendő célértékeket.

\section{A 2-es típusú cukorbetegség kezelése}

A terápia kezdő lépéseként el kell végezni az első betegoktatást. Fel kell világosítani a beteget magáról a cukorbetegségről, annak lehetséges szövődményeiről és a kezelési lehetőségekről, továbbá életmódi változtatásokra vonatkozó javaslatokat kell tenni, étrendre és a mozgásra, önellenőrzésre, lábápolásra vonatkozóan. A diétás tanácsadás 
során meg kell fogalmazni a konkrét javaslatokat, az étkezések számát, annak minőségi összetételét, szénhidrát- és kalóriatartalmát.

Amennyiben a háziorvos végzi a cukorbeteg gondozását, gondoskodni kell a megfelelő, szervezett diétás oktatáson való részvételről.

A 2-es típusú cukorbetegek döntő hányada az életmód-terápia mellett per os adható gyógyszeres kezelést is igényel, amelyek egy része hoszszabb ideje ismert és alkalmazott, más része az utóbbi idők fejlesztésének eredménye. A betegek egy részénél a kezelés az inzulint is magában foglalja. Napjainkban az injektábilis, nem-inzulinszerủ készítmények (GLP-1-mimetikumok) a kezelés új lehetőségét jelentik. Gyakori, hogy a monoterápiás gyógyszeres kezelés nem biztosít megfelelő anyagcserehelyzetet. Már az első viziten történhet gyógyszer bevezetése, ellenjavallat hiányában metformin formájában, de szövődménymentes, rövid betegségtartammal (<1 év) rendelkező, a glykaemiás kontrollt csak kismértékben meghaladó $\left(\mathrm{HbA}_{1 \mathrm{c}}<8,0 \%\right)$ betegség esetén hagyhatunk időt az önmagában folytatott életmódkezelés sikerességének. Ebben az esetben fokozottan figyelni kell arra, hogy a folyamatos gondozás ne szakadjon meg. Ugyanakkor jelentősebb $\mathrm{HbA}_{1 \mathrm{c}}$-emelkedés esetén megengedett kettős ( $\mathrm{HbA}_{1 \mathrm{c}}>8,0 \%$ esetén) és hármas $\left(\mathrm{HbA}_{1 \mathrm{c}}>9,0 \%\right.$ esetén) kombináció alkalmazása is. A 9,0\% feletti $\mathrm{HbA}_{1 \mathrm{c}}$ esetén, amenynyiben tünetek is jelentkeznek, inzulinterápia bevezetése javasolt.

A betegség kezelésének alapgyógyszerét jelentő metformin bevezetésekor fontos a kis adaggal való kezdés és a fokozatos dózisemelés általában 2000 mg-ig. Metformin első antidiabetikumként történő választását a 2-es típusú diabetes alapvető patogenetikai tényezőit befolyásoló természete (csökkenti az inzulinrezisztenciát, a GLP-1-elválasztás serkentésével közvetve javítja az inzulinelválasztást), keringési kockázatot csökkentő pleiotrop hatásspektruma, valamint az alkalmazásával kapcsolatos előírások betartása mellett biztonságos alkalmazása, kedvező ára indokolja. A metforminkezelés ellenjavallatait a 6. táblázat foglalja össze. $\mathrm{Az}$ első gyógyszeres kezelés bevezetése történhet az életmód-terápia megkezdésével egy időben vagy néhány hónappal később is. A metforminterápia bevezetése bizonyos feltételek esetén már a prediabetes stádiumában ajánlott. A legújabb szakmai ajánlások számos lehetőséget engednek kezdő lépésként, így a régóta használt szulfanilurea-szereket, a jelentősebb hyperglykaemiával járó esetekben $\left(\mathrm{HbA}_{1 \mathrm{c}}>9,0 \%\right)$ az inzulinkezelést, továbbá a DPP-4-gátlókat, GLP-1-receptoragonistákat, SGLT-2-gátlókat, glitazonokat (pioglitazont). Jelentősebb hyperglykaemia esetén kombinációs kezelés is indokolt lehet kezdő szerként (3. ábra).

A cukorbeteg kezelésében az egyik legfontosabb fordulópont a metformin vagy más kezdő OAD-kezelés megkezdése után 3 hónappal következik be. Amennyiben erre az időpontra nem sikerül az egyéni szempontokat is figyelembe vevő célértéket elérni, második, harmadik szer, további kombináció fokozatos bevezetésére van szükség (4. ábra). Ennek megválasztásához figyelembe kell venni a beteg veszélyeztetettségét az esetleges hypoglykaemia kialakulása estén, a beteg életkorát, a testsúlyt, a már kialakult szövődményeket, a társbetegségeket, különös tekintettel a veseelégtelenségre (5. ábra) és a kardiovaszkuláris állapotra, sőt a beteget körülvevő szocio-kulturális környezetre is. A mindenkori támogatási rendszer figyelembevételével a háziorvos mérlegeli a beteg diabetológushoz irányítását. A jelenleg háziorvosi hatáskörben is rendelhető szulfanilurea a hypoglykaemia és a testsúlynövekedés veszélye miatt csak végső esetben tanácsolt. Ilyenkor a gyógyszercsoporton belül lehetőség szerint a legkedvezőbb mellékhatás-profillal rendelkező gliclazidot használjuk.

Érdemes már a kezelés legelején felvetíteni az összes későbbi terápiás lépést, a kettős és hármas kombinációs lehetőségeket is.

\section{A 2-es típusú cukorbetegség gondozása - teendők a további viziteken}

Minden orvos-beteg találkozásnak elengedhetetlen eleme a betegoktatás. Minden alkalommal kérdezzük meg, hogy az előző alkalommal átadott edukációs anyagokból mire emlékszik, illetve mit sikerült megvalósítani, mik lehetnek az esetleges kudarcok okai, mik a tervei, miben tudunk segíteni. Kérjük meg betegünket, hogy vezessen étkezési naplót, melyben az elfogyasztott ételek és italok mellett feljegyezheti az elvégzett testmozgást is. Betegünket kérjük fel önellenőrzést elősegítő vércukormérő készülék vásárlására, és tanítsuk 
meg a mérési rendszerekre és az adatok értékelésére. Evidenciák bizonyítják az önellenőrzés hatékonyságát ún. „nem inzulin” kezelés esetén is.

Legalább 3 havonta szükséges a testsúly és a haskörfogat mérése, a BMI meghatározása, a vérnyomásmérés, az éhomi és a postprandialis vércukormérés, az önellenőrzést végző betegnél a kezelési napló alapján az anyagcsere-vezetés megbeszélése, a terápiahűség értékelése, megerősítése.

Évente legalább egy alkalommal elvégzendő a teljes körű vizsgálat úgy, mint a betegség felfedezésekor, különös tekintettel a lábvizsgálatra, teljes körű laboratóriumi vizsgálat (mint első alkalommal), a kezelés áttekintése, az önellenőrzési technika ellenőrzése. A $\mathrm{HbA}_{1 \mathrm{c}}$ meghatározása évente 2-4 alkalommal javasolt.

\section{A 2-es típusú cukorbetegség megelözése}

A 2-es típusú diabetest a szakirodalom ma megelőzhetőnek tartja. A megelőzésének leghatékonyabb eszköze az életmód-terápia: megfelelő táplálkozással a kívánatos testsúly elérése és/vagy megtartása, valamint a rendszeres fizikai aktivitás. A prevenciós tevékenység a cukorbetegség kialakulása vonatkozásában nagy kockázattal rendelkező személyek felkutatására, szűrésére és adott esetben kezelésére irányul. A 2-es típusú diabetes és kórmegelőző állapotai vonatkozásában fokozott kockázatot jelentő állapotokat a 21. táblázat összegzi.

\section{Egyéb feladatok}

A gesztációs diabetes gondozása diabetológiai ellátást tesz szükségessé. A terhesgondozás során azonban a háziorvos nyomon követi a GDM szűrését (18. táblázat). Fokozott kockázat (19. táblázat) esetén jelzi azt a szakellátásnak, követi a gesztációs diabeteses terhes diabetológiai ellátását. A szülést követően mint a 2-es típusú diabetesre nagy kockázatú egyént rendszeresen szűrővizsgálatban részesíti, szükség esetén nem-gyógyszeres és gyógyszeres kezelésbe vonja.

A háziorvos feladata a cukorbetegség sürgősségi állapotainak felismerése, helyszíni ellátása, az esetleges sürgősségi ellátás igénybevételének mér- legelése, szükség esetén a beteg sürgősségi osztályra irányítása, mentőszállítás igénylése. A sürgősségi állapotok felismeréséhez vércukor-önellenőrző készülék és vizelet gyorsteszt használatára szükség lehet.

A házorvos végzi a cukorbetegeket fokozottabb mértékben veszélyeztető betegségek prevencióját, többek között a fertőző betegségekkel szembeni immunizációját (influenza, pneumococcus-fertőzés elleni immunizáció).

\footnotetext{
Irodalom

1. Egészségügyi szakmai irányelv - A diabetes mellitus kórismézéséröl, a cukorbetegek antihyperglykaemiás kezeléséröl és gondozásáról felnőttkorban (szerk: Jermendy Gy, irta: Gaál Zs, Gerö L, Hidvégi T, Jermendy Gy, Kempler P, Winkler G, Wittmann I). Diabetologia Hungarica 2017; 25(1): 3-77.

2. VI. Magyar Kardiovaszkuláris Konszenzus Konferencia. Metabolizmus 2015; 13: 4-114.

3. Preiszinger A, Borda F, Oláh I, Kajetán M, Torzsa P: A háziorvos lehetőségei a 2-es típusú cukorbeteg gondozásában. Háziorvos Továbbképző Szemle 2014; 19: 695-701.
} 
